\title{
BOBOT POTONG, KARKAS, GIBLET DAN LEMAK ABDOMINAL AYAM BROILER YANG DIBERI GULA MERAH DAN KUNYIT DALAM AIR MINUM SEBAGAI FEED ADDITIVE
}

\author{
Wiesje M. Horhoruw, Rajab* \\ Jurusan Peternakan Fakultas Pertanian, Universitas Pattimura \\ Jln. Ir. M. Putuhena, Kampus Poka, Ambon 97233 \\ *Email : rajab.amir@gmail.com
}

\begin{abstract}
ABSTRAK
Penelitian ini bertujuan untuk mengetahui pengaruh pemberian gula merah dan kunyit sebagai feed additive dalam air minum terhadap bobot potong, bobot karkas, bobot giblet dan bobot lemak abdominal ayam broiler. Total sebanyak 90 DOC ayam broiler strain COBB dengan rataan bobot badan awal kurang lebih $37 \mathrm{~g}$, digunakan sebagai bahan percobaan selama 38 hari pemeliharaan. Penelitian ini menggunakan metode analisis ragam Rancangan Acak Lengkap (RAL) dengan tiga perlakuan yang dicobakan yaitu $\mathrm{P} 0=$ pemberian air minum tanpa herbal feed additive, $\mathrm{P} 1$ = pemberian air minum dengan herbal feed additive (gula merah $2 \%$ dan kunyit 10 gram), dan $\mathrm{P} 2=$ pemberian air minum dengan herbal feed additive (gula merah $2 \%$ dan kunyit 20 gram), dan masing-masing perlakuan terdiri atas 5 ulangan. Berdasarkan hasil penelitian dapat disimpulkan bahwa pemberian gula merah dan kunyit sebagai feed addtive dalam air minum tidak memberikan pengaruh yang berbeda terhadap bobot potong, bobot karkas, bobot giblet dan bobot lemak abdominal ayam broiler.
\end{abstract}

Kata kunci: Gula merah, kunyit, bobot potong, karkas, giblet, lemak abdominal, ayam broiler

\section{SLAUGHTERING WEIGHT, CARCASS, GIBLET AND ABDOMINAL FAT WEIGHT OF BROILER GIVEN BY PALM SUGAR AND CURCUMMA IN DRINGKING WATER AS FEED ADDITIVE}

\begin{abstract}
The aim of the research was to know effect of palm sugar and curcumma as feed addtive on slaughtering weight, carcass, giblet, and abdominal fat weight of broiler. Total of 90 tail of broiler (COBB strain) with DOC weight rate was $37 \mathrm{~g}$ used as experimentas materials rearing in 38 days. This research used analysis of varianve method of complete random design with 3 treatments and 5 replication was observed, there was $\mathrm{P} 0=$ without feed additive, $\mathrm{P} 1$ = using feed additive (palm sugar $2 \%$ and $10 \mathrm{~g}$ of curcumma), dan $\mathrm{P} 2=$ using feed additive (palm sugar $2 \%$ and $20 \mathrm{~g}$ of curcumma). The results showed that there was no significance effect of palm sugar and curcumma as feed addtive on slaughtering weight, carcass, giblet, and abdominal fat weight of broiler
\end{abstract}

Key words: Palm sugar, Curcumma, slaughtering weight, carcass, giblet, abdominal fat, broiler

\section{PENDAHULUAN}

Ayam broiler masih menjadi prioritras utama penyedia sumber protein hewani, dimana ayam broiler memiliki sifat-sifat yang menguntungkan, baik bagi para peternak maupun para konsumen. Adapun sifatsifat baik yang dimiliki ayam broiler adalah dagingnya empuk, kulit licin dan lunak, tulang rawan dada belum membentuk tulang yang keras, ukuran badan besar, dengan bentuk dada yang lebar, padat dan berisi, efisiensi terhadap pakan cukup tinggi dan sebagian besar dari makanan diubah menjadi daging, pertumbuhan atau pertambahan berat badan sangat cepat pada umur 5-6 minggu ayam bisa mencapai berat $\pm 2 \mathrm{~kg}$ (Rasyaf 1995 dalam Pratikno, 2010).

Berbagai penelitian telah banyak dilakukan untuk meningkatkan kualitas daging ayam broiler sehingga nilai jualnya pun dapat meningkat. Perbaikan pakan dan suplementasi merupakan cara yang banyak dilakukan, hal ini karena penggunaan pakan pada produksi ayam broiler mencapai sekitar 60-70\% dari total biaya produksi. Imbuhan pakan atau feed additives telah banyak digunakan pada pakan ayam untuk meningkatkan efisiensi penggunaan pakan, untuk membantu dalam proses pencernaan dan metabolisme yang diperlukan agar ransum yang dikonsumsi menjadi efisien digunakan oleh tubuh 
ayam. Pakan tambahan pelengkap (feed additive) tersebut untuk memacu pertumbuhan yang lebih baik atau produksi daging yang tinggi sebesar $66,8 \%$. Selain laju pertumbuhan yang cepat pada broiler selalu diikuti perlemakan yang cepat,dimana penimbunan lemak yang cenderung meningkat sejalan dengan bertambahnya umur. Oleh karena perlunya penambahan feed additive dalam pakan untuk mengurangi penimbunan lemak dalam tubuh (Jumiati dkk., 2017).

Herbal feed additive dapat dipakai untuk menggantikan antibiotik, misalnya temulawak (Curcuma xanthorrhiza) dan kunyit (Curcuma longa). Kandungan zat aktif kurkumin yang terkandung di dalam kunyit berfungsi sebagai antibakteri, penambah nafsu makan dan kecernaan bahan ransum. Zat aktif kurkumin yang diberikan pada ayam broiler mempengaruhi tingkat konsumsi, pertambahan bobot badan dan nilai konversi ransum (Sutaji 2012). Selain itu pertumbuhan jamur dapat dihambat oleh kandungan zat aktif xantorizol yang terdapat dalam temulawak (Purwanti 2008). Berbagai kandungan yang terdapat pada kedua tanaman tersebut diharapkan dapat digunakan sebagai alternatif pengganti antibiotik dalam meningkatkan performa ayam broiler. Penelitian ini bertujuan untuk mengetahui pengaruh pemberian gula merah dan kunyit sebagai feed additive dalam air minum terhadap bobot potong, bobot karkas, bobot giblet dan bobot lemak abdominal ayam broiler.

\section{BAHAN DAN METODE}

Penelitian ini dilaksanakan pada Unit Perkandangan Jurusan Peternakan Fakultas Pertanian Universitas Pattimura, dan berlansung selama tiga bulan mulai tahap persiapan sampai tahap pengumpulan dan analisis data.

Total sebanyak 90 DOC ayam broiler strain COBB dengan rataan bobot badan awal kurang lebih $37 \mathrm{~g}$, digunakan sebagai bahan percobaan selama 38 hari pemeliharaan. Dalam penelitian ini digunakan 15 petak kandang sistem litter dengan serbuk gergaji sebagai alas kandang, yang masing-masing berukuran $1 \mathrm{~m}^{2}$ dan dilengkapi tempat makan, tempat air minum dan lampu pijar 60 watt sebagai pemanas. Peralatan yang digunakan antara lain timbangan digital, termometer, perlengkapan kandang (seperti sekop, sapu, dan ember), dan blender.

Bahan pakan yang digunakan adalah pakan komersial berbentuk crumble merk BR-1 produksi PT. Japfa Comfeed Indonesia TBK, dengan bahan baku penyusunnya terdiri dari jagung kuning, soy bean meal, meat bone meal, asam amino esensial, palm oil, premix, vitamin, mineral esensial, dan corn gluten meal. Komposisi nutrien ransum mengandung air 12 $\%$, protein kasar 20,5-22,5 \%, lemak kasar minimal 5 $\%$, serat kasar maksimum $5 \%$, abu maksimum $7 \%$, kalsium 0,1 - 1,1 \%, phosphor minimum 0,5\%, coccidiostat + , antobiotika + , dan enzim + .

Air minum yang digunakan adalah air minum tanpa atau dengan herbal feed additives. Herbal feed additive terbuat dari campuran gula merah dan kunyit. Air minum merupakan air sumur. Gula merah berupa gula aren berbentuk segi empat yang dibungkus daun jati, digunakan sebanyak $2 \%$ dari jumlah air minum, diiris tipis dan dicampur dalam larutan kunyit. Sedangkan kunyit yang digunakan berwarna kuning tua, dicuci bersih dan dihaluskan dengan cara diblender dan dilarutkan dalam 1 liter air.

Selama 38 hari pemeliharaan, sebanyak 90 ekor ayam dipilih secara acak dan ditempatkan pada 15 petak kandang perlakuan yang telah difumigasi sebelumnya, dimana masing-masing petak berisi 6 ekor ayam untuk dikenakan secara acak salah satu dari 3 perlakuan dan 5 ulangan. Pemberian pakan disesuaikan dengan umur ternak. Ransum dan air minum diukur, dicatat, dan diberikan kepada ayam secara ad libitum.

Peubah yang diamati dalam penelitian ini meliputi: (1) bobot potong, merupakan bobot ayam broiler sesaat sebelum dipotong diukur menggunakan timbangan digital dalam satuan gram ; (2) bobot karkas, merupakan bobot karkas diukur menggunakan timbangan digital dalam satuan gram ; (3) bobot giblet, merupakan bobot organ hati, jantung dan rempela (gizzard) diukur menggunakan timbangan digital dalam satuan gram ; dan (4) bobot lemak abdominal, merupakan bobot lemak yang menempel pada gizzard dan rongga perut, diukur menggunakan timbangan digital dalam satuan gram.

Penelitian ini menggunakan metode analisis ragam Rancangan Acak Lengkap (RAL) dengan tiga perlakuan, dan masing-masing perlakuan terdiri atas 5 ulangan. Perlakuan yang dicobakan yaitu P0 = pemberian air minum tanpa herbal feed additive, $\mathrm{P} 1=$ pemberian air minum dengan herbal feed additive (gula merah $2 \%$ dan kunyit 10 gram), dan $\mathrm{P} 2=$ pemberian air minum dengan herbal feed additive (gula merah 2 $\%$ dan kunyit 20 gram). Data yang diperoleh ditabulasi, dan dianalisis menggunakan metode analisis ragam (ANOVA), bila terdapat perbedaan pengaruh perlakuan yang nyata maka dilanjutkan dengan uji pembandingan berganda Duncan (Duncan Multiple Range Test). Analisis data dilakukan dengan bantuan software statistik MINITAB versi 17.0.

\section{HASIL DAN PEMBAHASAN}

Hasil analisis rataan dan simpangan baku bobot potong, bobot karkas, bobot giblet dan bobot lemak abdominal ayam broiler yang diberi gula merah dan kunyit dalam air minum sebagai feed additive dalam penelitian ini seperti tertera pada tabel 1 . 
Tabel 1. Bobot potong, bobot karkas, bobot giblet dan bobot lemak abdominal ayam broiler yang diberi gula merah dan kunyit dalam air minum sebagai feed additive

\begin{tabular}{|c|c|c|c|}
\hline \multirow[t]{2}{*}{ Peubah yang diamati } & \multicolumn{3}{|c|}{ Perlakuan } \\
\hline & P0 & P1 & $\mathrm{P} 2$ \\
\hline Bobot potong (gr) ${ }^{\mathrm{TN})}$ & $1988,47 \pm 65,36$ & $2031,34 \pm 35,14$ & $2060,00 \pm 54,83$ \\
\hline Bobot karkas (gr) ${ }^{\mathbf{T N})}$ & $1516,60 \pm 66,32$ & $1538,60 \pm 40,88$ & $1546,67 \pm 30,82$ \\
\hline Bobot giblet $\left.(\mathrm{gr})^{\mathrm{TN}}\right)$ & $71,97 \pm 4,66$ & $75,07 \pm 5,83$ & $75,73 \pm 4,99$ \\
\hline Bobot lemak abdominal $(\mathrm{gr})^{\mathbf{T N}}$ & $31,97 \pm 3,24$ & $33,16 \pm 3,96$ & $30,60 \pm 5,32$ \\
\hline
\end{tabular}

Ket : ${ }^{\mathrm{TN})}$ Superscript menunjukkan tidak terdapat perbedaan yang nyata antar perlakuan $(\mathrm{P}>0,05)$

\section{Bobot Potong Ayam Broiler}

Rataan bobot potong ayam broiler strain Cobb yang digunakan dalam penelitian ini dan dipotong pada umur 38 hari yaitu sebesar 1988,47 gr untuk perlakuan P0, 2031,34 gr untuk perlakuan P1, serta 2060 gr untuk perlakuan P2. Berdasarkan hasil penelitian seperti terlihat pada Gambar 1, terlihat bahwa pemberian air minum dengan herbal feed additive berupa gula merah $2 \%$ dan kunyit 20 gram (perlakuan P2) memberikan pengaruh lebih baik terhadap rataan bobot potong ayam broiler dibanding perlakuan lainnya, namun hasil analisis ragam menyimpulkan bahwa tidak terdapat perbedaan yang nyata $(\mathrm{P}>0,05)$ antar perlakuan.

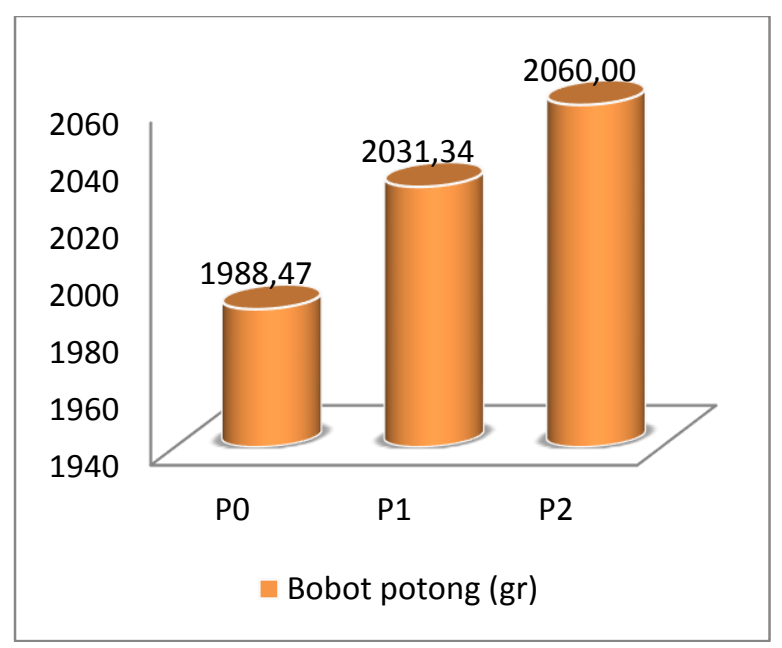

Gambar 1. Bobot potong ayam broiler yang diberi gula merah dan kunyit dalam air minum sebagai feed additive

Gambar 1 memperlihatkan bahwa bobot potong ayam broiler yang memperoleh perlakuakn P2 dalam penelitian ini lebih tinggi daripada perlakuan lainnya. Hal ini karena tingkat konsumsi ransum ayam pada P2 juga lebih tinggi. Konsumsi ransum merupakan cermin dari masuknya sejumlah unsur nutrien ke dalam tubuh ayam. Jumlah ransum yang masuk ini harus sesuai dengan yang dibutuhkan untuk produksi dan untuk hidupnya. Tingkat konsumsi ransum akan memengaruhi laju pertumbuhan dan bobot akhir karena pembentukan bobot, bentuk, dan komposisi tubuh pada hakekatnya adalah akumulasi pakan yang dikonsumsi ke dalam tubuh ternak (Blakely dan Blade,
1994 dalam Setiadi dkk., 2017). Selain itu pemberian kunyit diduga juga berpengaruh terhadap konsumsi ransum ayam. Kunyit memiliki kandungan gizi berupa kurkumin. Kurkumin berfungsi meningkatkan organ pencernaan ayam broiler dengan merangsang dinding kantong empedu untuk mengeluarkan cairan empedu dan merangsang keluarnya getah pankreas yang mengandung enzim amilase, lipase dan protease yang berguna untuk meningkatkan pencernaan bahan pakan seperti karbohidrat, lemak dan protein. Selain itu minyak atsiri yang dikandung kunyit juga dapat mempercepat pengosongan isi lambung $\mathrm{Hal}$ ini menimbulkan keterikatan antara fungsi dari kunyit terhadap proses konsumsi dan konversi pakan ayam broiler yang berpengaruh dalam pembentukan daging serta dapat menghasilkan pertambahan berat badan ayam broiler yang optimal (Bintang dan Nataamijaya, 2005 dalam Kristia dkk., 2016).

Hasil penelitian menunjukkan bahwa pemberian campuran gula merah dan kunyit dalam air minum tidak berbeda pengaruhnya terhadap bobot badan ayam broiler bila dibandingkan dengan tanpa penggunaan feed additive herbal tersebut dalam air minum. Aktivitas pemeliharaan ayam broiler dalam lingkungan yang sama, dipelihara dalam kandang yang sama, diberi ransum dengan jumlah dan kandungan nutrisi yang sama, serta dipotong pada periode waktu yang bersamaan akan berdampak terhadap nilai rataan bobot potongnya yang tidak berbeda signifikan secara statistik. Aliyani (2002) menyatakan bahwa bobot potong ayam broiler selain faktor bibit/strain umumnya dipengaruhi oleh faktor aktivitas dan kondisi lingkungan pemeliharaan, konsumsi pakan, kualitas ransum dan lama waktu pemeliharaan.

\section{Bobot Karkas Ayam Broiler}

Bobot karkas diperoleh dari hasil penimbangan ayam broiler setelah dipotong, dan dibersihkan dari darah dan bulu, serta dikeluarkan bagian kepala sampai batas pangkal leher, kaki pada bagian shank, dan organ dalam. Rataan bobot karkas ayam tiap perlakuan dalam penelitian ini yaitu masing-masing sebesar 1516,60 gr untuk perlakuan P0, 1538,60 gr untuk perlakuan P1, dan 1546,67 gr untuk perlakuan P2 (Gambar 2). Bila dihitung dalam bentuk persentase yang merupakan rasio bobot karkas terhadap bobot potong dikalikan $100 \%$ maka rataan persentase karkasnya adalah $76,40 \%$ untuk perlakuan P0, 75,66 
\% untuk perlakuan $\mathrm{P} 1$, dan 75,05\% untuk perlakuan $\mathrm{P} 2$. Dari hasil penelitian terlihat bahwa pemberian air minum dengan herbal feed additive berupa gula merah $2 \%$ dan kunyit 20 gram (perlakuan P2) memberikan pengaruh lebih baik terhadap rataan bobot karkas ayam broiler dibanding perlakuan lainnya, namun hasil analisis ragam menyimpulkan bahwa tidak terdapat perbedaan $(\mathrm{P}>0,05)$ antar perlakuan.

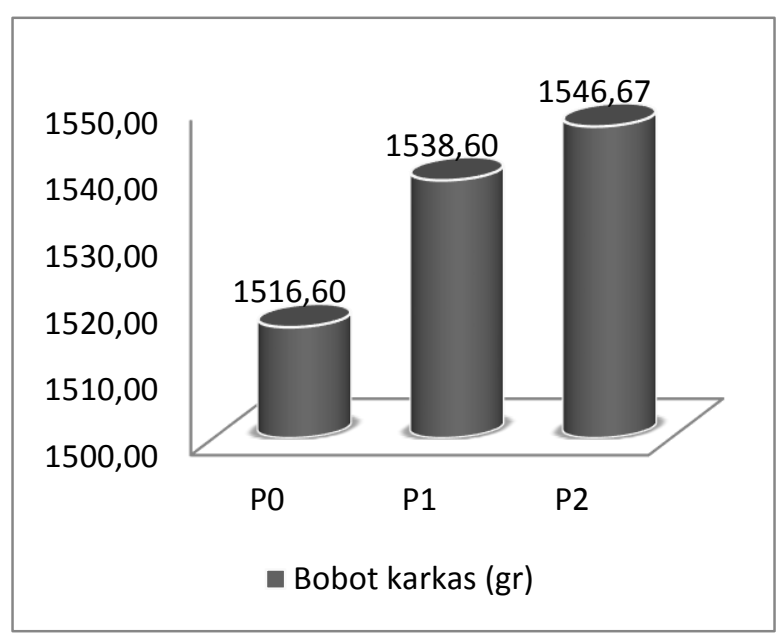

Gambar 2. Bobot karkas ayam broiler yang diberi gula merah dan kunyit dalam air minum sebagai feed additive

Hasil penelitian menunjukkan bahwa ayam broiler pada perlakuan P2 memiliki bobot karkas yang lebih tinggi dibanding perkaluan lainnya, hal ini karena ayam tersebut memiliki bobot potong yang lebih tinggi pula seperti ditunjukkan pada Gambar 1. Bobot karkas seekor ayam berkorelasi positif atau memiliki hubungan yang erat dengan bobot hidup ayam saat dipotong, artinya bila bobot potong ayam tinggi maka bobot karkasnya akan tinggi pula (Ahmad dan Herman, 1982). Berdasarkan persentase karkasnya maka ayam broiler dalam penelitian cukup baik yaitu berkisar antara 75,05 - 76,40\%. Bila dibandingkan dengan hasil penelitian lainnya yang memperoleh persentase karkas ayam broiler berkisar antara 65-75\% dari bobot hidup (Salam dkk., 2013), rataan persentase berat karkas ayam broiler umur 5 minggu adalah 5963\% dari berat hidup (Suprayitno dan Indraji, 2007), sedangkan menurut Sumarni (2015) menyatakan bahwa rataan persentase bobot karkas 69,76-73,39\%, maka persentase karkas dalam penelitian ini lebih tinggi, hal ini karena umur pemotongan yang berbeda dimana ayam broiler dalam penelitian ini dipotong pada umur 6 minggu.

Hasil analisis statistik menunjukkan bahwa pemberian gula merah dan kunyit sebagai feed additive dalam air minum dengan level berbeda tidak memberikan pengaruh yang signifikan terhadap bobot karkas ayam broiler. Dengan demikian dapat disimpulkan bahwa gula merah dan kunyit tidak mempunyai pengaruh terhadap perbedaan peningkatan bobot karkas ayam broiler. Penggunaan galur ayam broiler, jenis kelamin, umur pemotongan ayam, kondisi lingkungan pemeliharaan dan pemberian pakan yang sama atau seragam juga berdampak terhadap tidak adanya perbedaan bobot karkas ayam. Menurut Subeki dkk. (2012) dalam Jumiati dkk., (2017) menyatakan bahwa faktor yang mempengaruhi bobot atau persentase karkas adalah bangsa, umur, jenis kelamin, pakan, kondisi fisik dan lemak abdominal. Lemak dan jeroan merupakan hasil ikutan yang tidak dihitung dalam persentase karkas, jika lemak tinggi maka persentase karkas akan rendah. Faktor lainnya yang sangat berperan dalam pembentukan karkas ayam adalah kandungan protein ransum (Setiadi dkk., 2011).

\section{Bobot Giblet Ayam Broiler}

Bobot giblet diperoleh dari hasil penimbangan organ dalam (hati, jantung, dan rempela (gizzard)) ayam broiler setelah dipotong. Hati merupakan salah satu organ di dalam tubuh, yang berperan dalam proses seleksi empedu untuk mengabsorbsi lemak, penyimpanan hasil metabolisme karbohidrat, lemak dan protein, mensintesis plasma protein yang diperlukan dalam penggumpalan darah, memproduksi dan memecah butir-butir darah, menyimpan glikogen dan vitamin yang larut dalam lemak. Hati juga berperan dalam detoksifikasi, pembentukan sel darah merah serta metabolisme dan pembentukan vitamin (Ressang, 1984 ; Ganong, 1979 dalam Walad, 2007). Fungsi jantung sebagai pompa dan motor penggerak dalam peredaran darah dan kerjanya bersifat otonom atau dikendalikan oleh sistem syaraf pusat di luar kemauan atau kesadaran. Besar jantung tergantung jenis kelamin, umur, bobot badan dan aktivitas hewan (Ressang, 1984 dalam Maulana, 2007). Rempela terdiri atas otot merah, tebal dan kuat serta berfungsi untuk menghancurkan butir-butir pakan sebelum masuk ke dalam usus halus (Brake et al., 1993).

Giblet merupakan hasil ikutan karkas ayam yang dapat dikonsumsi oleh manusia seperti hati, rempela/gizzard, dan jantung (USDA, 2008 dalam Arifah, 2016; Snyder dan Orr, 1964 dalam Suryanah dkk., 2016). Pengaruh pemberian gula merah dan kunyit dalam air minum terhadap bobot giblet ayam broiler dalam penelitian ini seperti ditunjukkan pada Gambar 3. Hasil penelitian menunjukkan rataan bobot giblet adalah sebesar 71,97 ; 75,07 dan 75,73 gr masing-masing untuk perlakuan P0, P1 dan P2. Dari Gambar 3 memperlihatkan bahwa pemberian air minum dengan herbal feed additive berupa gula merah $2 \%$ dan kunyit 20 gram (perlakuan P2) tampak memberikan pengaruh lebih tinggi terhadap rataan bobot giblet ayam broiler dibanding perlakuan lainnya. Hal ini disebebabkan karena ayam broiler pada perlakuan P2 memiliki bobot hidup yang lebih tinggi dibanding perlakuan lainnya. Bobot giblet berkorelasi positif dengan bobot hidup, dimana makin tinggi bobot gidup maka bobot giblet juga makin tinggi. 
Hasil analisis ragam menunjukkan bahwa tidak terdapat perbedaan $(\mathrm{P}>0,05)$ bobot giblet ayam broiler antar perlakuan. Meskipun gula merah dan kunyit sebagai feed additive dapat merangsang tingkat konsumsi ayam broiler, namun tidak signifikan berperan dalam peningkatan bobot organ dalam ayam broiler seperti hati, jantung dan rempela.

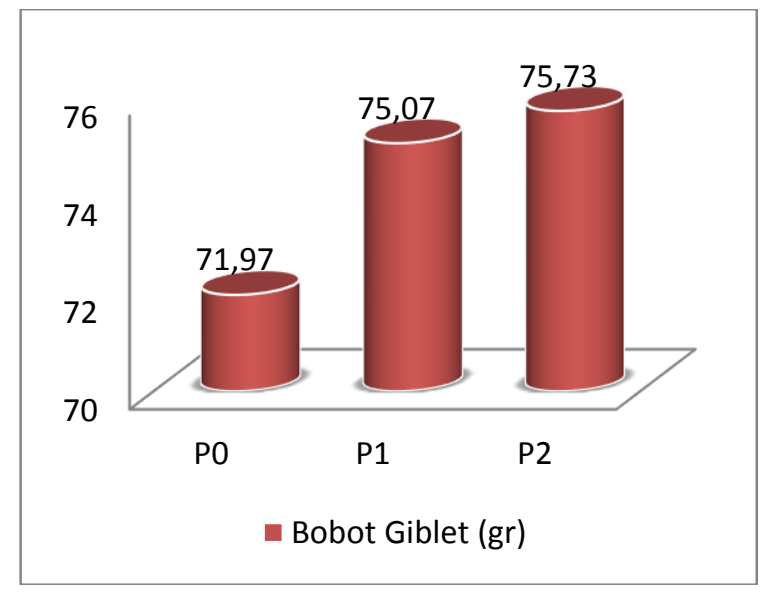

Gambar 3. Bobot giblet ayam broiler yang diberi gula merah dan kunyit dalam air minum sebagai feed additive

\section{Bobot Lemak Abdominal Ayam Broiler}

Bobot lemak abdominal dalam penelitian ini didapat dari hasil penimbangan lemak dari batas proventrikulus sampai batas atas cloaca (banyak terletak di sekeliling gizzard dan sedikit di jantung). Menurut Piliang dan Djojosoebagio (2006), salah satu tempat penyimpanan lemak adalah rongga perut (abdomen) dimana jaringan adipose berperan dalam proses penyimpanan lemak tersebut. Lemak abdominal adalah lemak yang berada di sekeliling gizzard, organ reproduksi, otot abdominal, usus dan sekitar kloaka.

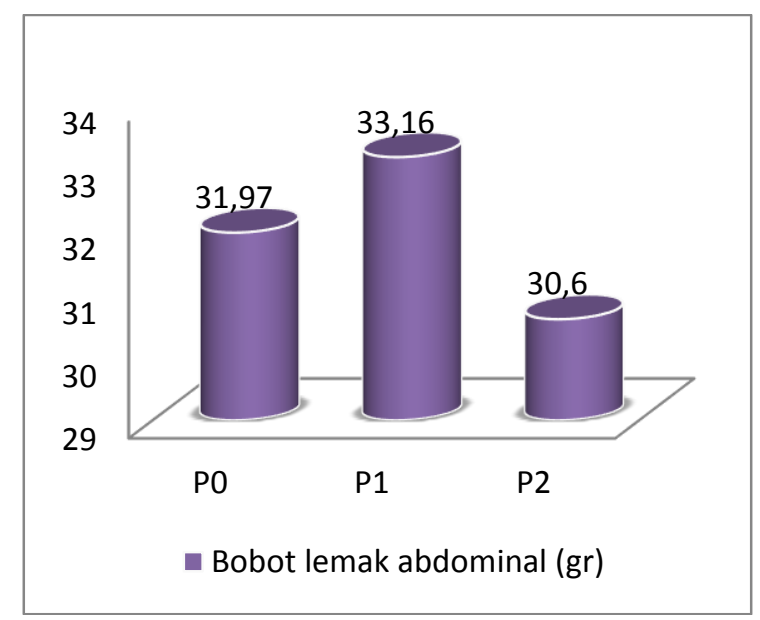

Gambar 4. Bobot lemak abdominal ayam broiler yang diberi gula merah dan kunyit dalam air minum sebagai feed additive
Pengaruh pemberian gula merah dan kunyit dalam air minum terhadap bobot lemak abdominal ayam broiler dalam penelitian ini seperti ditunjukkan pada Gambar 4. Rataan bobot lemak abdominal ayam menurut perlakuan yaitu masing-masing sebesar 31,97 gr untuk perlakuan P0, 33,16 gr untuk perlakuan P1, dan 30,60 gr untuk perlakuan P2. Hal penelitian menunjukkan bahwa penggunaan kunyit lebih banyak dalam air minum yaitu sebesar 20 gr (perlakuan P2) dapat menurunkan bobot lemak abdominal ayam broiler. Kecenderungan penurunan bobot lemak abdominal ini diduga berkaitan dengan peran aktif senyawa kurkuminoid yang terkandung dalam kunyit. Senyawa kurkuminoid mempunyai aktivitas kolagoga yang berfungsi meningkatkan produksi dan sekresi empedu, yang membantu dalam proses pemecahan lemak (Riayadi, 2002).

Hasil analisis ragam menunjukkan bahwa tidak terdapat perbedaan pengaruh pemberian gula merah dan kunyit sebagai feed additive dalam air minum terhadap bobot lemak abdominal ayam broiler. Hal ini karena tidak ada perbedaan strain, jenis kelamin dan umur ayam, serta tingkat energi dan komposisi ransum yang digunakan dalam penelitian ini. Jensen et al. (1987) berpendapat bahwa kadar lemak abdominal dipengaruhi oleh komposisi ransum, jenis kelamin dan umur ayam, serta tingkat energi ransum.

\section{SIMPULAN}

Berdasarkan hasil penelitian dapat disimpulkan bahwa pemberian gula merah dan kunyit sebagai feed addive dalam air minum tidak memberikan pengaruh yang berbeda terhadap bobot potong, bobot karkas, bobot giblet dan bobot lemak abdominal ayam broiler.

\section{DAFTAR PUSTAKA}

Ahmad, B., dan R. Herman. 1982. Perbandingan Produksi Daging antara Ayam Jantan Kampung dan Ayam Jantan Petelur. Media Peternakan. 25(1): 3-6.

Aliyani, A. 2002. Persentase berat karkas dan organ dalam ayam broiler yang diberi tepung daun talas (Colocasia esculenta L. Schott) dalam ransumnya. [Skripsi]. Bogor: Fakultas Kedokteran Hewan, Institut Pertanian Bogor.

Arifah, J. 2016. Pengaruh pemberian pakan mengandung bubuk kayu manis (Cinnamonum burmanii) terhadap persentase karkas, giblet dan lemak abdominal ayam broiler. [Skripsi].: Bogor: Departemen Ilmu Nutrisi dan Teknologi Pakan, Fakultas Peternakan, Institut Pertanian Bogor.

Brake, J., G. B. Havenstein, S. E. Scheideler, P. R. Ferket, and D. V. Rives. 1993. Relationship 
of sex, age, and body weight to broiler carcass yield and offal production. Poultry Sci. Journal. 72: 1137-1145.

Jensen, L. S., A. Brenes, and K. Takahashi. 1987. Effect of early nutrition on abdominal fat of broiler. Poultry Sci. Journal. 66: 15171523.

Jumiati, S., Nuraini, dan R. Aka. 2017. Bobot Potong, Karkas, Giblet dan Lemak Abdominal Ayam Broiler yang Temulawak (Curcumaxanthorrhiza,Roxb) dalam Pakan. Jurnal Ilmu Peternakan Tropis. 4(3): 11-19.

Kristia, D. N. W., S. Hadi, R. B. Utomo, dan M. Lamid. 2016. Pengaruh Pemberian Tepung Kunyit (Curcuma Domestica) dan Tepung Daun Seligi (Phyllanthus Buxifolius) dalam Pakan Terhadap Performans Ayam Broiler Jantan. Jurnal Agrovet. 9(2): 19-29.

Maulana, I. 2007. Pengaruh warna lampu indukan terhadap bobot hidup, persentase karkas, giblet dan lemak abdominal ayam broiler. [Skripsi]. Bogor: Program Studi Teknologi Produksi Ternak, Fakultas Peternakan, Institut Pertanian Bogor.

Piliang, W. G., dan S. Djojosoebagio. 2006. Fisiologi Nutrisi Volume I. Bogor: IPB Press.

Riayadi, S. 2002. Bau kotoran dan CRD hilang. Majalah Invovet. 39: 33-34.

Salam. S., A. Fatahilah, D. Sunarti, dan Isroli. 2013. Berat Karkas dan Lemak Abdominal Ayam Broiler yang diberi Tepung Jintan Hitam (Nigella sativa) dalam Ransum selama Musim Panas. Sains Peternakan. 11(2): 8489.

Setiadi, D., K. Nova, dan S. Tantalo. Perbandingan Bobot Hidup, Karkas, Giblet, dan Lemak Abdominal Ayam Jantan Tipe Medium dengan Strain Berbeda yang Diberi Ransum Komersial Broiler. Artikel Jurnal Jurusan Peternakan Universitas Lampung. Hal 1-7.

Subeki K., H. Abbas., dan K.A. Zura. 2012. Kualitas
Karkas (Berat Karkas, Persentase Karkas Dan Lemak Abdomen) Ayam Broiler yang Diberi Kombinasi CPO (Crude Palm Oil) dan Vitamin C (Ascorbic Acid) dalam Ransum sebagai Anti Stress. Jurnal Peternakan Indonesia. 14 (3): 447-453.

Sumarni. 2015. Pengaruh kuantitas ransum terhadap persentase karkas, giblet dan lemak abdominal ayam broiler. [Skripsi]. Kendari: Fakultas Peternakan, Universitas Halu Oleo.

Suprayitno, dan M. Indradji. 2007. Efektivitas Pemberian Ekstrak Temulawak (Curcumae xanthoriza) dan Kunyit (Curcumae domestica) sebagai Immunostimulator Flu Burung pada Ayam Niaga Pedaging. Jurnal Animal Production. 9(3): 178-183.

Suryanah, H. Nur, dan Anggraeni. 2016. Pengaruh Neraca Kation Anion Ransum yang Berbeda Terhadap Bobot Karkas dan Bobot Giblet Ayam Broiler. Jurnal Peternakan Nusantara. 2(1): 1-8.

Sutaji. 2012. Pengaruh Metode dan Dosis Pemberian Temulawak (Curcuma xanthorriza roxb) terhadap Performa Broiler. Jurnal Cendikia. 10: 23-30.

Pratikno, H. 2010. Pengaruh Ekstrak Kunyit (Curcuma Domestica Vahl) Terhadap Bobot Badan Ayam Broiler (Gallus Sp). Buletin Anatomi dan Fisiologi. 18(2): 39-46.

Purwanti, S. 2008. Kajian efektifitas pemberian kunyit, bawang putih dan mineral zink terhadap performa, kadar lemak, kolesterol dan status kesehatan broiler. [Skripsi]. Bogor: Fakultas Kedokteran Hewan, Institut Pertanian Bogor.

Walad, G. S. 2007. Pengaruh warna lampu penerangan terhadap bobot hidup, persentase karkas, giblet dan lemak abdominal ayam broiler. [Skripsi]. Bogor: Program Studi Teknologi Produksi Ternak, Fakultas Peternakan, Institut Pertanian Bogor. 